\title{
Conceptualizing and Isolating Cultural Differences in Performance Data in International High Technology Industrial Markets
}

Citation for published version (APA):

de Ruyter, J. C., Wetzels, M. G. M., \& van Birgelen, M. J. H. (2001). Conceptualizing and Isolating Cultural Differences in Performance Data in International High Technology Industrial Markets. Industrial Marketing Management, 30(1), 23-35. https://doi.org/10.1016/S0019-8501(99)00076-0

Document status and date:

Published: 01/01/2001

DOI:

10.1016/S0019-8501(99)00076-0

Document Version:

Publisher's PDF, also known as Version of record

Please check the document version of this publication:

- A submitted manuscript is the version of the article upon submission and before peer-review. There can be important differences between the submitted version and the official published version of record.

People interested in the research are advised to contact the author for the final version of the publication, or visit the DOI to the publisher's website.

- The final author version and the galley proof are versions of the publication after peer review.

- The final published version features the final layout of the paper including the volume, issue and page numbers.

Link to publication

\footnotetext{
General rights rights.

- You may freely distribute the URL identifying the publication in the public portal. please follow below link for the End User Agreement:

www.umlib.nl/taverne-license

Take down policy

If you believe that this document breaches copyright please contact us at:

repository@maastrichtuniversity.nl

providing details and we will investigate your claim.
}

Copyright and moral rights for the publications made accessible in the public portal are retained by the authors and/or other copyright owners and it is a condition of accessing publications that users recognise and abide by the legal requirements associated with these

- Users may download and print one copy of any publication from the public portal for the purpose of private study or research.

- You may not further distribute the material or use it for any profit-making activity or commercial gain

If the publication is distributed under the terms of Article 25fa of the Dutch Copyright Act, indicated by the "Taverne" license above, 
NORTH-HOLLAND

\section{Conceptualizing and}

Isolating Cultural

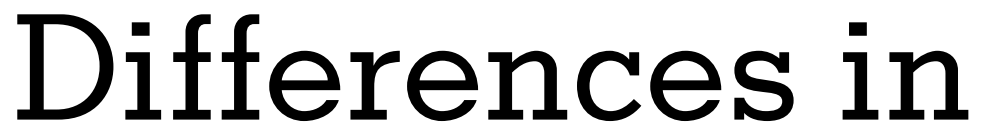

Performance Data in

\section{International High-Tech}

\section{Industrial Markets}

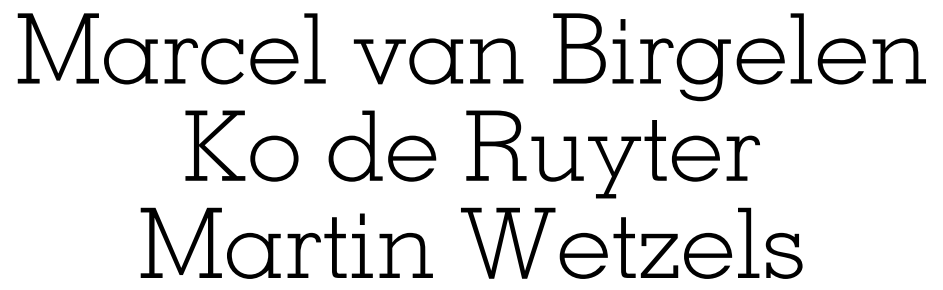

Address correspondence to Marcel van Birgelen, Maastricht University, Faculty of Economics and Business Administration, Department of Marketing and Marketing Research, P.O. Box 616, 6200 MD Maastricht, The Netherlands. Tel.: +31-43-3883839; Fax: +31-43-3210265; E-mail: m.vanbirgelen@mw.unimaas.nl
In high-technology industrial markets, a shift can be observed from the mere delivery of industrial products to a total-productoffering, including both products and accompanying services. Because of the heterogeneity in buyers' demands, the measurement of an organization's performance on such total-product-of- 
ferings becomes quite difficult. This problem gets even more serious when one is trying to compare the relative performance of international subsidiaries, since factors such as cultural differences and their influence on how customers report on performance have to be taken into account. This article attempts to conceptualize cultural differences and uses these for establishing international equivalence in customer survey data on the performance on a high-tech total-product-offering. The results of an empirical study reveal that cultural differences indeed influence international performance measurement. After correction for these differences, conclusions can be drawn on the relative performance of different subsidiaries. Furthermore, it is shown that intangible service elements in a high-tech total-product-offering have the strongest influence on customer satisfaction. (c) 2000 Elsevier Science Inc. All rights reserved.

\section{INTRODUCTION}

Organizations operating in high-technology markets frequently face high levels of uncertainty and perceived risk [1]. On the one hand, sellers must attempt to over-

MARCEL VAN BIRGELEN is a Ph.D. Candidate at the Department of Marketing and Marketing Research at Maastricht University, the Netherlands. His main research interests include international marketing research, problems and challenges in the interaction between (international) marketing researchers and decision makers, services marketing, and relationship marketing. The journals he has published in include the International Business Review, the Journal of Business and Industrial Marketing, the European Journal of Marketing, Total Quality Management, and various Dutch managerial journals.

KO DE RUYTER is an Associate Professor of Marketing and Marketing Research at Maastricht University, the Netherlands. His research interests include services marketing, customer information technology, customer complaining behavior, service innovations, and relationship marketing. His work has appeared in the International Journal of Research in Marketing, Advances in Services Marketing and Management, the Journal of Economic Psychology, and Total Quality Management.

MARTIN WETZELS is an Assistant Professor at the Department of Marketing and Marketing Research at Maastricht University, the Netherlands. His current research interests include the management of service organizations, services marketing, quantitative methods in marketing, and marketing channels. The journals he has published in include the International Journal of Research in Marketing, the Journal of Economic Psychology, the European Journal of Marketing, Advances in Services Marketing and Management, the International Journal of Logistics Management, the Journal of Business and Industrial Marketing, and Total Quality Management. come hesitancies towards new technological products and services that their customers may have, while dealing with the continuous threat of competitors developing new technologies [2-4]. From a buyer perspective, it can be seen that buyers are confronted with high switching costs and asymmetrically dependent relationships, once they have adopted a technology from one specific seller [5-7]. To cope with the risks and uncertainties associated with high-technology industrial markets, sellers are attempting to find more effective ways of marketing their product offerings. In addition to providing buyers with quality products, sales persons' expertise, after-sales services, and effective communication are crucial factors for a supplier's success rate [8-11]. In other words, buyers of high-technology products are searching for more than just a good product. They also demand additional services and support in case some problem arises and, therefore, they are looking for a total-product-offering.

The demand for such a total-product-offering posits a number of challenges, both for marketing practitioners and marketing researchers. While both core product technology and a portion of accompanying services might be subject to a certain degree of standardization (e.g., delivery of additional supplies), it often remains difficult to achieve or guarantee uniformity in service levels. As customers are important participants in the service delivery process and no two customers are precisely equal, the service component of the total-product-offering (e.g., repair visit by a service engineer) may be heterogeneous [12]. This nonstandardization issue makes it difficult for practitioners and marketing researchers to assess, control, and measure both performance on service quality and buyers' satisfaction with these services.

This problem becomes even more serious when trying to study and compare customer evaluative judgements in international markets. To evaluate the relative performance of subsidiaries located in different countries, a multinational high-technology company inevitably has to take the cultural background of a country into account. To be able to make reliable inferences on the performance of international subsidiaries, it is necessary to separate or filter real subsidiary performance from cultural influences that might affect the way in which customers report on this perceived performance. In other words, international customer survey data on total-product-offering performance has to be made as much internationally equivalent as possible. In this article, we try to conceptualize and isolate cultural differences when studying the performance on a total-product-offering and its influence 


\section{Cultural background must be taken into account.}

on overall customer satisfaction in an international hightech business-to-business setting. Only after isolation and correction for these differences, comparative conclusions on relative subsidiary performance can be drawn and used for managerial purposes.

The article is structured as follows. First, we provide a brief conceptualization of the total-product-offering in high-tech industrial markets. Subsequently, some general issues in international marketing research and the role of culture in international marketing (research) activities are discussed. After conceptualizing and operationalizing culture, we will report on the results of an empirical study designed to isolate and correct customer survey data for cultural differences to obtain international equivalent data on subsidiary performance. We conclude the article with a discussion of a number of theoretical and managerial implications for researchers and decision makers.

\section{CONCEPTUALIZATION OF THE TOTAL-PRODUCT-OFFERING}

Buyers in high-tech industrial markets are frequently looking for a total-product-offering [13-15]. Moller [16] states that customers base their preference for a certain supplier on a set of multiattribute choice objects. These multiattribute choice objects refer to the variety of elements that make up a total-product-offering. The customers' final attitude towards a supplier is based on the supplier's performance on each of the individual attributes of this total-product-offering [17]. The total-product-offering is comparable to a supplier's offer portfolio, a concept that was introduced by Hakansson [18]. It is a set of variables that traditionally have been associated with supplier selection. A supplier's total offering is then represented by the core product and peripheral services [19, 20]. According to MacKenzie [21], the core product essentially relates to product performance and outcome quality. After-sales service for preventive or corrective product maintenance is an example of a peripheral service [20]. Therefore, the total-product-offering contains both functional, or product-related characteristics, and intangible, or service-related characteristics [11]. It is increasingly recognized that providing additional services is quite important for the generation of financial revenues $[8,11,12,22]$. Furthermore, it has been shown that in high-technology markets higher credibility of product and service quality results in higher levels of customer trust in a supplier [23]. A positive relationship between an adequate customer perception of the total-product-offering and customer trust also was found by MacKenzie [21] in the market for office equipment.

The importance of a high-quality total-product-offering is obvious, both for companies operating in domestic as well as in international markets. However, from a multinational company's perspective, problems arise with respect to international marketing research with the objective of comparing the performance on a total-productoffering, due to the cultural diversity between countries. In the next section, we discuss some general issues that have to be taken into consideration when conducting international marketing research.

\section{ISSUES IN INTERNATIONAL MARKETING RESEARCH}

In the development of international marketing strategies, information is of crucial importance for making effective marketing decisions [24]. The complexity of international markets, together with the large differences between countries, and the unfamiliarity with new markets lead to an increased need for international marketing research to solve strategic and tactical marketing problems. In marketing research that transcends borders, cross-cultural issues are involved that normally do not have to be considered when conducting marketing research on a national basis.

In contrast to the marketing discipline, cross-cultural studies and their problems have a long tradition in social sciences. In these disciplines extensive literature exists in which specific methodological and conceptual problems 


\section{A total-product-offering compares to an offer portfolio.}

in cross-cultural research are being addressed. Basically, these problems can be classified into (1) very basic problems and causes of cross-cultural difficulties, which lead to (2) a variety of more detailed and specific problems [25]. The first basic problem with cross-cultural marketing research is the researcher's self-reference, which might endanger the construct equivalence of a study [26]. This refers to the fact that researchers interpret reality from other cultures with beliefs, meanings, and ideas originated in the researcher's home culture. Hofstede and Spangenberg [27] refer to this as an ethnocentric bias, in which ethnocentrism is seen as an extreme tendency to view other groups, cultures or races as inferior to one's own reference group. Self-reference affects each phase in the research process, but especially the conceptualization of research questions and constructs, the development of measures, sampling, and the analysis and interpretation of results.

The second basic problem refers to the interaction between cultural and research-specific aspects, which might represent a threat to measurement equivalence. It addresses the issue, whether or not certain research designs and measures can be used in cross-cultural research and if they really identify cross-cultural differences [28]. Measurements in international research could be affected by different sociocultural reactions of respondents to measurement instruments, by the way in which the research is executed, and by lacking adaptations of sampling procedures to different local environments. The consequence of this could be results that are quite difficult to interpret $[29,30]$. The more detailed and specific problems in cross-cultural marketing research that follow from the basic problems relate to the various steps of doing international marketing research. Among others, these are the formulation of research problems, development of models, establishing equivalence in survey data, and analysis and interpretation of the obtained data. In the next section, we zoom in on an important issue in international marketing research, the role that a country's culture plays in conducting international marketing re- search and studying marketing-related factors, such as customer satisfaction and evaluations of an international total-product-offering's performance.

\section{CULTURE: ITS ROLE IN INTERNATIONAL MARKETING (RESEARCH)}

The reason for considering the impact that culture has on marketing in general, and research on customer evaluations of marketing activities in particular, has its origin in the subjective character of culture. The prominent role that subjectivity plays can be illustrated best by considering the central construct in this article, customer satisfaction. Satisfaction with the products that customers buy or the services they experience already has received substantial attention in the marketing literature. Customer (dis)satisfaction is a subjective interpretation of the objective evaluative comparison between expectations and perceptions [31]. Comparing expectations and perceptions results in an evaluation of the quality or performance of a specific provider of goods or services. This subjective interpretation of quality or performance represents a major source of heterogeneity in a judgement like customer satisfaction. Satisfaction on the basis of an evaluation of the interaction between customer and manufacturer/provider will be strongly determined by subjective factors. One such subjective factor is the cultural value system that people maintain. Oliver [32] suggests that values can be seen as predisposing conditions for desires and as such determinants of consumer expectations, which in turn form a comparison standard for satisfaction judgements.

Values can be studied from different perspectives. Values are both a characteristic of individual persons, as well as of larger collectivities [33]. On this latter, more macro-oriented level, values can be characterized as country or culture specific. Values are generally defined as "a broad tendency to prefer certain states of affairs over others" (p. 19) [33]. The subjective character of values is exemplified by Hofstede [33] himself who states 


\section{Satisfaction is influenced by subjective cultural values.}

that "because our values are programmed early in our lives, they are non-rational" (p. 19). An essential element of the definition of values is that they lead to subjective preferences and desires, which are expressed by people in their daily life activities and therefore also in their consumption of products and/or services. Values are important for determining a society's culture, since "Culture, .... includes systems of values, and values are among the building blocks of culture" (p. 25) [33]. Through its underlying values, culture is likely to be a determinant of the expectations on the basis of which customers form their subjective satisfaction evaluation. In addition to expectations, there is also a subjective dimension attached to customers' perceptions of product or service performance [12]. Therefore, from a macro perspective, both performance perceptions and expectations will be influenced by the values a person is maintaining and consequently the culture he/she is raised in. This indicates the importance of taking a country's culture into consideration when studying and comparing an international total-product-offering's performance and relating it to customer satisfaction. The next section provides a further conceptualization of culture and identifies a number of dimensions along which culture can be operationalized.

\section{CULTURE: A CONCEPTUALIZATION AND OPERATIONALIZATION}

The intention of this study is to conceptualize and isolate cultural differences in international customer survey data on an organization's performance on an industrial total-product-offering. By isolating these differences, equivalent data should be obtained from which real performance and differences between subsidiaries can be assessed. Now, the important question must be raised of how to conceptualize "culture"? One of the leading and most-cited academics in studies on national cultures is Geert Hofstede. According to Hofstede [34], culture can be regarded as "mental programs" or "mental software," indicating that individuals carry patterns of thinking, feeling, and potential acting that are learned throughout their lifetime. Culture can be defined as "the collective programming of the mind which distinguishes the members of one group or category of people from another" ( $p$. 5) [34]. After extensive international research, Hofstede [34] distinguishes between four dimensions of culture, which are aspects of a culture that can be measured relative to other cultures. These four dimensions together constitute a four-dimensional model of differences between national cultures. In this model, individual countries are characterized by a score on each of the four dimensions. These scores are represented by indices, one for each dimension.

The first dimension is called "power distance" and reflects the differences in how countries handle the fact that people are unequal. Power distance is defined as "the extent to which the less powerful members of institutions and organizations within a country expect and accept that power is distributed unequally" (p. 28) [34]. It is represented by the "power distance index" (PDI). In countries with higher PDI scores, differences in power distribution are more common and accepted than in countries with lower PDI scores. The second dimension is "collectivism versus individualism," represented by the "individualism index" (IDV). This dimension is defined as follows: "Individualism pertains to societies in which the ties between individuals are loose: everyone is expected to look after himself or herself and his or her immediate family. Collectivism as its opposite pertains to societies in which people from birth onwards are integrated into strong, cohesive in-groups, which throughout people's lifetime continue to protect them in exchange for unquestioning loyalty" (p. 51) [34]. High IDV scores point towards individualist countries, low scores towards collectivist countries. Dimension three is "femininity versus masculinity," where "femininity pertains to societies in which social gender roles overlap" (p. 82) [34] (both men and women are modest, tender, concerned with quality of life) and "masculinity pertains to societies in which so- 


\section{Effective services management requires leveroging cultural differences.}

cial gender roles are clearly distinct" (p. 82) [34] (men are assertive, tough, focussed on material success, whereas women are more modest, tender, concerned with quality of life). It is represented by the "masculinity index" (MAS), for which higher scores indicate masculine countries and lower scores feminine countries. The final dimension is referred to as "uncertainty avoidance," defined as "the extent to which the members of a culture feel threatened by uncertain or unknown situations" (p. 113) [34]. It is represented by the "uncertainty avoidance index" (UAI), where high UAI scores point in the direction of countries strongly avoiding uncertainty and low UAI scores of countries with weak uncertainty avoidance.

In the international delivery of services, differences on cultural dimensions should be considered and leveraged to manage services more effectively [35]. When we relate the cultural dimensions to the purpose of our study, we can use them as a proxy for the cultural characteristics of a country and correct international customer survey data on the performance on an internationally marketed high-tech total-product-offering for these characteristics. In this way, we take a country's culture, and the underlying subjective value system, into consideration, which enables us to obtain cross-national equivalent data and to compare the real relative performance of subsidiaries located in these countries. After having discussed the role of culture in international marketing (research) and conceptualized it into dimensions, we will now proceed by reporting on the results of an empirical study that was undertaken to isolate and correct for cultural differences in an industrial high-technology setting.

\section{AN EMPIRICAL STUDY}

\section{Research Setting and Sampling}

The empirical study was conducted in the international market of office equipment and focussed on copying equipment. According to the definition of Meldrum [36,] this market can be considered high-tech in the sense that products are subject to rapid developments in a highly technical environment (e.g., integration and digitization of different technologies) and that relatively high levels of technology-based uncertainty are associated with these products, both by buyers and sellers. This uncertainty stems from the high financial costs that are intertwined with the rapid advances in technology in this market (e.g., systems integration, automated remote sensing, and artificial intelligence). Moreover, as a result of the increased modular build-up of copying technology customers are required to play a more active role by means of "self-service" after sales activities, which in turn leads to increased levels of perceived risk.

The total-product-offering contains both functional, or product characteristics, and intangible, or service characteristics [11]. In this market, customers do not only demand high-quality copiers, they also need additional supplies and services for operating the copiers. In fact, the total-product-offering is a process consisting of a number of subsequent steps. In our study, the process is operationalized by four important steps, which were determined on the basis of interviews with managers that have been active in this market for a longer period of time. The core product represents the first step of the total-productoffering. The second step refers to supplies since no product in this market can function properly without additional supplies (e.g., paper and toner). In case some problem arises, the customer will request a service visit by a service technician who should solve the problem. Therefore, step three is the service call by the customer. Finally, step four is the actual service visit made by the service technician after receiving a service call.

The manufacturer participating in the study has operating companies located in more than 30 countries worldwide. The data for this study was gathered from samples of customers of subsidiaries in four different countries: The Netherlands, Norway, the United Kingdom, and Austria. The customers were sent a questionnaire, which was accompanied by a personalized cover letter and a postage-paid return envelope, addressed to the university. A total number of 9125 questionnaires were sent to customers in these four countries. 2327 questionnaires were 


\section{Performance on intangibles determines satisfaction most strongly.}

returned, which represents a response rate of $25.5 \%$. The number of questionnaires received per country was as follows: 659 for the Netherlands, 609 for Norway, 800 for the United Kingdom, and 259 for Austria. Differences in sample size are reflective of the relative size of the market in each country. Respondents were active in a variety of functions, such as sales managers, operations managers, buyers, and general managers/owners.

\section{Questionnaire Development and Reliability Analysis}

In the design of customer satisfaction surveys, it is recommended that the questionnaire should be structured around the structure of the business [37]. Within each process, the issues that the customer considers relevant should be considered, and questions have to be worded in the customer's language. An essential part of developing a questionnaire for an international study is the establishment of construct equivalence of the constructs to be measured. In essence, this means that the meaning and interpretation of the items in the questionnaire has to be same across the participating countries. The establishment of construct equivalence is necessary before one can continue to establish equivalence in how respondents react to the measures (measurement equivalence), the type of equivalence we are aiming at in this study. If there is no construct equivalence, subjects are not responding to the same stimuli.

The procedure that we followed for developing an international questionnaire with a high level of construct equivalence consisted of four steps. First, we conducted four focus group interviews with managers of the subsidiaries in each of the four countries to generate items that are important for measuring the performance on each of the four steps of the total-product-offering. Second, the questionnaire was developed by formulating the various items, with which customers can give their performance perception relative to their expectations. In addition to the items generated by means of the focus group inter- views, items were included that incorporate the dimensions of the well-known SERVQUAL instrument designed by Parasuraman, Zeithaml, and Berry [38] for measuring service quality. The preliminary questionnaire was double-back translated into each of the four languages of the countries participating in our study [39]. Third, we went back to the subsidiaries and conducted several interviews to assess the managers' opinions on the questionnaire. Where necessary, we adapted it on the basis of the comments that we were given during the interviews. Finally, we quantitatively pretested the questionnaire with small samples of customers in the four countries. This procedure ultimately resulted in a questionnaire, which adequately covers the constructs that we want to measure.

Items are measured on a 9-point scale, ranging from 1 "much worse than expected" to 9 "much better than expected", also referred to as the expectancy disconfirmation method suggested by Cronin and Taylor [40] for measuring service quality. Step 1 ("product") is measured by four items, which cover the products' features, the copy/print quality, the products' failure rate, and the ease of use. Step 2 ("supplies") is operationalized by six items, relating to for example the ordering, delivery, and the quality of the supplies. Four items measure step 3 ("service call"). For this step in the process, items were asked on the accessibility of the manufacturer when communicating a problem, the feedback on the time when the problem will be solved, and the competence and understanding of the company's call handling staff. The last step ("service visit") is measured by 10 items, referring to, for example, time duration between service call and arrival of the service technician, time taken for the repair, the technician's ability to solve the problem, and the way in which technicians present themselves. The customers' overall evaluation of their satisfaction with the totalproduct-offering is measured by a single-item scale ranging from 1 "very dissatisfied" to 9 "very satisfied."

After data collection, reliability analysis was conducted to assess the internal consistency of the measure- 


\section{Equivalence allows for cross-national performance assessments.}

ment scales and check if they were reliable enough in measuring the variables of interest in this study. For the overall sample, Table 1 presents the so-called $\alpha$ reliability scores of the various scales. All scores well-exceed the critical value of 0.70 proposed by Nunally and Bernstein [41], indicating that the scales are sufficiently reliable. Also, the reliability scores within the individual countries turned out to be sufficiently high enough, ranging from 0.81 to 0.84 for product, 0.89 to 0.94 for supplies, 0.87 to 0.93 for service call, and 0.93 to 0.94 for service visit. In addition to the ex ante establishment of construct equivalence, we also conducted a post hoc analysis to check this type of equivalence. To validate if the questions are equally understood across the four countries, we conducted a Mokken scale analysis [4244] for the scales that we used. The theory on which this analysis is based can be viewed as a probabilistic version of Guttman scale analysis for dichotomous items or more generally as a nonparametric approach to item response theory. It enables the analysis of scales that have more than two answer categories and often is applied to validate measurement instruments of abilities, attitudes, and personality traits. By means of Mokken analysis, we can investigate the invariance of item response patterns between groups of respondents. The analysis makes it possible to formally check the cross-national understanding of the scales by assessing whether or not the relative structure or response patterns of each of the scales is equivalent between the four countries. From the Mokken scale analysis, it could be concluded that the response patterns for each of the four countries indeed show simi-

TABLE 1

Overall Reliability of the Scales

\begin{tabular}{lc}
\hline Scale & Reliability $(\alpha)$ \\
\hline Product & 0.83 \\
Supplies & 0.92 \\
Service call & 0.91 \\
Service visit & 0.94 \\
\hline
\end{tabular}

lar patterns. This conclusion is based on the fact that the monotone homogeneity and double monotonicity of the response patterns were well within acceptable values (see Mokken [42] for a further discussion of the Mokken scale analysis procedure). The results of this post hoc analysis, indicating similarity in response patterns, serve as an extra proof of having used an adequate questionnaire that was equally understood in the four countries.

\section{Correcting for Cultural Differences and Results}

In this study, the cultural characteristics of the four participating countries were not explicitly measured by including cultural items in the questionnaire. The culture of a country is represented by the scores on the four dimension indices by Hofstede [34], which were added after all the customer data on performance and overall satisfaction had been collected. Each respondent was assigned four index scores, one for each cultural dimension. The scores on these indices are country specific, meaning that they are equal for respondents within a country and different between countries. This is in accordance with Hofstede's [34] definition of culture as being "the collective programming of the mind ..." (p. 5). Table 2 gives an overview of the index scores per country.

To correct the customers' performance evaluations of the four elements of the total-product-offering and their overall satisfaction for cultural characteristics, we made use of the principles of a statistical technique called analysis of covariance (ANCOVA). When ANCOVA is applied, dependent variable means are adjusted for what-

TABLE 2

Index Scores on Cultural Dimensions

\begin{tabular}{lcccc}
\hline Country & $\begin{array}{c}\text { Power } \\
\text { Distance } \\
\text { (PDI) }\end{array}$ & $\begin{array}{c}\text { Individualism } \\
\text { (IDV) }\end{array}$ & $\begin{array}{c}\text { Masculinity } \\
\text { (MAS) }\end{array}$ & $\begin{array}{c}\text { Uncertainty } \\
\text { Avoidance } \\
\text { (UAI) }\end{array}$ \\
\hline The Netherlands & 38 & 80 & 14 & 53 \\
Norway & 31 & 69 & 8 & 50 \\
United Kingdom & 35 & 89 & 66 & 35 \\
Austria & 11 & 55 & 79 & 70 \\
\hline
\end{tabular}


ever differences there are between groups on the relevant covariate [45]. Translating this idea to the current study, we apply ANCOVA for the performance evaluations of the four steps of the total-product-offering (i.e., product, supplies, service call, and service visit) and for overall satisfaction, being the dependent variables, to correct for between-country differences in the covariates represented by the four cultural dimensions (i.e., power distance, collectivism vs. individualism, femininity vs. masculinity, and uncertainty avoidance). For the purpose of illustration a formal, mathematical, formula for the calculation of adjusted means is included. This formula has the following form:

$$
\mathrm{Y}_{(\mathrm{adj})}=\mathrm{Y}-\mathrm{b}\left(\mathrm{X}_{\mathrm{j}}-\mathrm{X}\right)
$$

where $\mathrm{Y}_{(\mathrm{adj})}=$ adjusted mean of a dependent variable; $\mathrm{Y}=$ mean of that variable before adjustment; $b=$ common regression coefficient of the covariate on the dependent variable $\mathrm{Y} ; \mathrm{X}_{\mathrm{j}}=$ mean of group $\mathrm{j}$ on the covariate; $\mathrm{X}=$ grand mean of the covariate calculated over the total number of groups. In this study, not group means but individual scores are adjusted with a quantity that is the same within a country and different between countries. Presenting the previous formula in managerial terms could lead to the following example. Suppose that individualism (IDV) is the only cultural dimension that significantly influences perceived product performance, then customer evaluations of this performance should be adjusted for the impact of differences on this cultural dimension. In other words, the effect of individualism should be filtered out. To do this we would need (1) the product performance score, (2) the impact score of individualism on product performance (common regression coefficient), (3) the country-specific individualism score, and (4) the average individualism score of the countries that were included in the research. The earlier mentioned formula then would like this:

$$
\begin{gathered}
\text { production performance }_{(\text {adj })}=\text { product performance }- \\
\text { impact score of IDV on product performance } \\
\text { (country-specific IDV-score-mean IDV-score } \\
\text { over countries included })
\end{gathered}
$$

By applying this method, each respondent's evaluation score with regard to product performance is adjusted for cross-cultural differences pertaining to individualism.

Following this example, the common regression coefficients for the four cultural dimension covariates have been calculated by five regression equations, four with the performance on the separate steps of the total-product-offering as dependent variable and one with overall customer satisfaction as dependent variable. However, when performing the regression analyses with ordinary least squares the problem of multicollinearity between the cultural dimensions arose, meaning that the dimensions are highly correlated with each other. This means that it is hard to assess what the unique impact of each dimension is. The main reason for this is the limited variance on the cultural dimensions, since respondents in one country were assigned the same scores on the indices. This multicollinearity results in estimates that are unstable and have large variances. Hoerl and Kennard [46, 47] proposed a procedure referred to as ridge regression that enables analysts to cope with multicollinearity. By allowing the estimators to be biased, estimates will have a smaller variance and become more stable. This bias is represented by a constant $k$, also known as the bias parameter, which can be determined by examining the ridge trace (see Montgomery and Peck [48] for further discussion). Thus, the built-in bias allows us to assess the unique effect of each cultural dimension. The final results of the ridge regressions for this study are presented in Table 3.

From the F-values in Table 3, it can be concluded that the cultural influence on the dependent variables is significant. The variance explained by the cultural dimensions ranges from $1 \%$ for products, service call, and service visit to $3 \%$ for supplies.

\begin{tabular}{|c|c|c|c|c|c|}
\hline $\begin{array}{l}\text { Cultural } \\
\text { Dimension }\end{array}$ & Products & Supplies & $\begin{array}{c}\text { Service } \\
\text { Call }\end{array}$ & $\begin{array}{c}\text { Service } \\
\text { Visit }\end{array}$ & $\begin{array}{c}\text { Overall } \\
\text { Satisfaction }\end{array}$ \\
\hline PDI & $0.0011^{\mathrm{b}, \mathrm{c}}$ & $-0.0041^{*}$ & $0.0034^{\mathrm{c}}$ & $0.0023^{\mathrm{c}}$ & $0.0048 *$ \\
\hline IDV & $0.0019^{c}$ & $0.0018^{c}$ & $0.0031 *$ & $0.0018^{\mathrm{c}}$ & $-0.0011^{\mathrm{c}}$ \\
\hline MAS & $0.0012 *$ & $0.0038 * * *$ & $0.0010^{c}$ & $0.0006^{\mathrm{c}}$ & $-0.0020 * *$ \\
\hline UAI & $0.0096 * * *$ & $0.0075 * * *$ & $0.0127 * * *$ & $0.0104 * * *$ & $0.0158 * * *$ \\
\hline F-value & $6.41 * * *$ & $13.09 * * *$ & $7.20 * * *$ & $5.92 * * *$ & $14.44 * * *$ \\
\hline$R^{2}$ & 0.01 & 0.03 & 0.01 & 0.01 & 0.02 \\
\hline $\begin{array}{l}{ }^{\mathrm{a}} \mathrm{k}=0.5 . \\
{ }^{\mathrm{b}} \text { Regressiol } \\
{ }^{\mathrm{c}} \text { Not signif } \\
{ }^{*} P<0.05 . \\
{ }^{*} P<0.0 \\
* * * P<0 .\end{array}$ & $\begin{array}{l}\text { coefficient } \\
\text { icant at } \alpha= \\
001 .\end{array}$ & $\begin{array}{l}(\beta) \\
0.05 .\end{array}$ & & & \\
\hline
\end{tabular}

The significant ridge regression coefficients now can be used to calculate the adjusted scores on the perfor-

TABLE 3

Results of Ridge Regression Analyses ${ }^{a}$ 
mance evaluations of the product, supplies, the service call, the service visit, and overall satisfaction. Table 4 presents the changes that can be attributed to differences on the significant cultural dimensions. A positive sign indicates that the reported score on a scale is increased due to cultural differences, a negative sign refers to a decrease of the reported score. Overall it can be concluded from Table 4 that scores in Austria are most strongly influenced by differences on the cultural dimensions.

Finally, after adjusting for cultural differences, the true relationship between the subsidiaries' total-product-offering performance and overall customer satisfaction is assessed by using regression analysis. Structural subsidiary performance is determined by including three dummy variables in the analysis, with subsidiaries in home country the Netherlands as reference group. The results of this regression analysis are rendered in Table 5.

From Table 5, it can be concluded that, after adjustment for cultural differences, the performance on the intangible service element of the total-product-offering is the strongest determinant of overall customer satisfaction. Both performance during the service call and the service visit are positively related to customer satisfaction. Of the tangible elements of the total-product-offering performance on the product has the strongest positive influence on satisfaction, followed by the performance on additional supplies. When considering structural differences in performance between the four countries, one can see that only the subsidiary in the United Kingdom scores significantly lower on satisfaction, compared with The Netherlands, Norway, and Austria. From internal benchmark reports, we learned that the result for the United Kingdom actually represented a well-known problem to the manufacturer, which was due to a lower performance level. Overall, the subsidiary in the Netherlands scores the highest on customer satisfaction with the total-product-offering.

\section{TABLE 4}

Changes in Means on Total-Product-Offering Performance and Satisfaction

\begin{tabular}{lrrrrr}
\hline Country & Products & Supplies & $\begin{array}{c}\text { Service } \\
\text { Call }\end{array}$ & $\begin{array}{c}\text { Service } \\
\text { Visit }\end{array}$ & $\begin{array}{c}\text { Overall } \\
\text { Satisfaction }\end{array}$ \\
\hline The Netherlands & 0.02 & -0.08 & 0.07 & 0.05 & 0.16 \\
Norway & -0.01 & -0.09 & 0.00 & 0.02 & 0.09 \\
United Kingdom & -0.09 & 0.00 & -0.13 & -0.13 & -0.25 \\
Austria & 0.26 & 0.41 & 0.21 & 0.23 & 0.16 \\
\hline
\end{tabular}

TABLE 5

Regression Analysis on Overall Total-Product-Offering Satisfaction

\begin{tabular}{lcrrrrr}
\hline $\begin{array}{l}\text { Independent } \\
\text { Variable }\end{array}$ & $\begin{array}{c}\text { Regression } \\
\text { Coefficient } \\
(\beta)\end{array}$ & \multicolumn{1}{c}{$\mathrm{t}$} & $P$ & F-Value & $R^{2}$ \\
\hline Product & 0.30 & 9.90 & $<0.0001$ & $206.07^{*}$ & 0.50 \\
Supplies & 0.09 & 2.67 & 0.0076 & & \\
Service call & 0.38 & 10.69 & $<0.0001$ & & \\
Service visit & 0.37 & 9.51 & $<0.0001$ & & \\
United Kingdom & -0.25 & -3.42 & 0.0006 & & \\
Norway & -0.05 & -0.52 & n.s. ${ }^{a}$ & & \\
Austria & -0.12 & -1.13 & n.s. & & \\
\hline
\end{tabular}

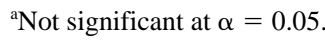

$* P<0.0001$.

\section{CONCLUSIONS AND IMPLICATIONS}

\section{Discussion}

International marketing research gives rise to several problems [25]: basic problems like the researcher's selfreference and the interaction between culture and research methodology, and more specific problems throughout the various steps of the research process. In this article, we paid attention to the influence of a country's cultural characteristics on the reported performance on a total-product-offering in a high-tech industrial market. By taking cultural differences between countries into account and adjusting cross-national customer data for these differences, equivalent data is obtained that can be used for further analysis on the relative performance of different subsidiaries. Culture can be described along the four dimensions found by Hofstede [34]. Our results suggest that there indeed exist culturally determined differences in the way respondents in different countries report on subsidiaries' total-product-offering performance and overall satisfaction. Culture seemed to have the highest impact in Austria, followed by the United Kingdom, and The Netherlands. In Norway the impact is the lowest, the performance scores on the four steps of the total-product-offering and overall customer satisfaction are not strongly influenced by the cultural characteristics of the country.

Once cross-national equivalence in the customer data has been established, they can be used to study general relationships between total-product-offering performance and customer satisfaction. Furthermore, comparisons can be made between the relative performance of a multinational's subsidiaries that are located in different countries. In this study, we found the strongest significant re- 
lationships between performance on service elements, the service call and the service visit, and overall satisfaction. This result supports the previous conclusion of Shaw et al. [11] that in high-tech industrial markets high importance should be attributed to intangible attributes for companies to be successful. Customers attach importance to aspects like accessibility, responsiveness, competence, and understanding of the call handling staff and service technicians. The copier itself turned out to be the most important tangible element of the total-product-offering for the establishment of customer satisfaction. Additional supplies play a limited, although still significant, role for achieving satisfaction. Finally, when looking at subsidiaries' relative performance on the total-productoffering it can be concluded that the United Kingdom does a significantly worse job in getting customers satisfied. The performance is the best for the subsidiary in the Netherlands, followed by Norway and Austria. However, the difference between these last three countries is not significant.

\section{Theoretical and Managerial Implications}

The strength of a study follows from the acknowledgement of its limitations. The limitations of our research give rise to new ideas and developments regarding the way in which cultural differences can be taken into account when doing international marketing research in an industrial setting. First, more attention should be paid to the conceptualization and measurement of cultural characteristics. The use of Hofstede's [34] cultural dimensions for assessing and dealing with differences between countries should be validated in future research in this setting, this in spite of the fact of their frequent use in previous cross-cultural research in other areas. This could be done by allowing segments of each country participating in the study to respond to the original survey instrument of Hofstede to confirm the reliability of the cultural measures and to compare inter- and intracountry cultural scores. Since the manufacturer already agreed on continuing the study in the years to come, we actually find ourselves in the position to measure and validate the cultural dimensions by including some extra items in the future questionnaire.

Another point related to the measurement of culture is that, in this study, all customers in one country were assigned the same score on the cultural indices, based on review of the literature. This method is feasible since culture is considered to be a collective programming of the mind. The consequence of this, however, is simplification and limited variability on the cultural dimensions within a country. Therefore, mainly for the purpose of validation of our method, future research should attempt to measure culture on an individual level, which will be done when the study is continued. The individual measurements can then be aggregated into overall scores for the cultural characteristics in one country. This procedure could lead to more precise estimates of the cultural influence, which has its impact on the accuracy of adjustments in the construct measurements. In addition to Hofstede's original items, an interesting alternative might be Schwartz's value scheme on the basis of which pancultural dimensions can be defined [49]. For this scheme, a measurement instrument on an individual level instead of an aggregated level has been developed.

Third, concepts were measured at one point in time, thus essentially from a static perspective. It may be worthwhile to study customer evaluative judgements over time to be able to take the dynamics of business relationships into account. Moreover, should such an approach be taken, measures of actual behavior and objective performance (e.g., switching behavior, vulnerability to price competition, relative market share) in addition to perceptual gauges could be taken into account. As was already mentioned, the study will be continued on a longitudinal basis, which enables us to study this temporal dimension of relationships between buyers and sellers and to include additional variables.

Another suggestion for future research relates to the composition of the subsamples within each country. It can be argued that there might exist differences between customers who are residents and customers who are expats from other countries but who live in a particular country. In case these ex-pats would be included in a country's sample, this could be resulting in skewness of the results. Due to the fact that in this study we made use of the manufacturer's customer database, which was unique for each country, we expect the number of ex-pats in each subsample and the bias it might cause to be very limited. However, by taking a respondent's country-oforigin into consideration, future research could check for the presence of ex-pats and, if necessary, control for potential differences between residents and these ex-pats.

Finally, no conceptual explanations were given for the influence that the cultural dimensions have on performance and satisfaction. This was done mainly because it is beyond the scope of the present study to explain differences in the relative impact, but we aim at using Hof- 
stede's cultural framework as an instrument for correcting for cultural influences. As can be concluded from Table 3, the impact of the four dimensions differs for each type of performance and for customer satisfaction. Future research should try to go deeper into the underlying cultural reasons for the various effects that were found.

The main and most important managerial implication of this study directly follows from the establishment of cross-cultural equivalence in the survey data. By taking cultural differences into account and adjusting performance measurements for these differences, organizations in high-tech industrial markets are now able (1) to assess and understand the true relationship between their performance on a high-tech total-product-offering and overall customer satisfaction, and (2) to compare the relative performance of subsidiaries located in different countries. Especially this last implication is of great importance to a multinational's success. It enables industrial organizations to identify subsidiaries that demand more attention and provides a thorough basis on which managerial efforts and resources can be allocated more effectively to subsidiaries that need it most strongly.

\section{REFERENCES}

1. Beard, C. R., and Easingwood, C. J.: Sources of Competitive Advantage for the Marketing of High-Tech Products and Processes in the UK. European Journal of Marketing 26, 7-20 (1992).

2. Beard, C. R.: Issues and Uncertainties for High-Tech Marketers, Proceedings of the World Marketing Congress, Melbourne July 6-10, 8, 44-51 (1995).

3. Moriarty, R. T., and Kosnik, T. J.: High-Tech Marketing: Concepts, Continuity, and Change. Sloan Management Review 30, 7-17 (1989).

4. Shanklin, W. L,. and Ryann J. K. Jr.: Essentials of Marketing High-Technology. Lexington Books, Lexington, MA, 1987.

5. Heide, J. B., and Weiss, A. M.: Vendor Consideration and Switching Behavior for Buyers in High-Technology Markets. Journal of Marketing 59, 30-43 (1995).

6. Jackson, B. B.: Winning and Keeping Industrial Customers. Lexington Books, Lexington, MA, 1985.

7. Wilson, D. T.: An Integrated Model of Buyer-Seller Relationships. Journal of the Academy of Marketing Science 4 (23), 335-345 (1994).

8. Abratt, R.: Industrial Buying in High-Tech Markets. Industrial Marketing Management 15, 293-298 (1986).

9. Kassicieh, S. K. and Rogers, R. D.: Microcomputer Purchase Criteria Across Industries. Industrial Marketing Management 11, 9-15 (1986).

10. Mayer, W. U.: Situational Variables and Industrial Buying. Journal of Purchasing and Materials Management Winter, 21-26 (1983).

11. Shaw, J., Giglierano, J., and Kallis, J.: Marketing Complex Technical Products: The Importance of Intangible Attributes. Industrial Marketing Management 18, 45-53 (1989).
12. Zeithaml, V. A., and Bitner, M. J.: Services Marketing, McGraw-Hill, Inc., New York, 1996.

13. Krapfel, R. E., Salmond, D., and Spekman, R.: A Strategic Approach to Managing Buyer-Seller Relationships. European Journal of Marketing 9(25), 22-37 (1991).

14. Turnbull, P. W.: A Review of Portfolio Planning Models for Industrial Marketing and Purchasing Management. European Journal of Marketing 3 (24), 7-22 (1990).

15. Yorke, D. A., and Droussiotis, G.: The Use of Customer Portfolio Theory. Journal of Business and Industrial Marketing 3(9), 6-18 (1994).

16. Moller, K.: Buying Behavior of Industrial Components: Inductive Approach for Descriptive Model Building, in Research in International Marketing, P. W. Turnbull and S. J. Paliwoda, eds., Croom Helm, London, 1986.

17. Weitz, B. A., and Wensley, R., eds.: Readings in Strategic Marketing: Analysis, Planning, and Implementation, Dryden Press, Harcourt Brace Javonovich, New York, 1988.

18. Hakansson, H.: International Marketing and Purchasing, John Wiley and Sons Ltd., Chichester, United Kingdom, 1982.

19. Grönroos, C.: Service Management and Marketing. Managing the Moments of Truth in Service Competition, Lexington Books, Lexington, MA/Toronto, 1990.

20. Lapierre, J.: Service Quality: The Construct, Its Dimensionality and Its Measurement. Advances in Services Marketing and Management 5, 45-70 (1995).

21. MacKenzie, H. F.: Partnering Attractiveness in Buyer-Seller Relationships. Unpublished Ph.D. Thesis, University of Western Ontario, Canada, 1992.

22. VanderMerwe, S., and Lovelock, C.: Competing through Services. Strategy and Implementation. Prentice Hall, Englewood Cliffs, NJ, 1994.

23. Meldrum, M., and Milman, A. F.: Ten Risks in Marketing High-Technology Products. Industrial Marketing Management 20, 1-8 (1991).

24. Douglas, S. P., and Craig, C. S.: International Marketing Research. Prentice Hall, Englewood Cliffs, NJ, 1983.

25. Holzmüller, H. H.: Konzeptionelle und Methodische Probleme in der Interkulturellen Management- und Marketingforschung, Schäffer-Poeschel Verlag, Stuttgart, 1995.

26. Jahoda, G.: Theoretical and Systematic Approaches in Cross-Cultural Psychology, in Handbook of Cross-Cultural Psychology, Vol. 1: Perspectives, H. C. Triandis and W. W. Lambert, eds., Allyn and Bacon, Boston, MA, 1980, 69-132.

27. Hofstede, G., and Spangenberg, J.: Internationale(n) Vergleiche, Technik der, in Handwörterbuch Export und Internationale Unternehmung, $\mathrm{K}$. Macharzina and M. Welge, eds., Poeschel Stuttgart, 1989, 948-963.

28. Angelmar, R., and Pras, B.: Verbal Rating Scales for Multinational Research. European Research 6, 62-67 (1978).

29. Adler, N. J.: Cross-Cultural Research: The Ostrich and the Trend. Academy of Management Review 2, 226-232 (1983).

30. Adler, N. J.: A Typology of Management Studies Involving Culture. Journal of International Business Studies 2, 29-47 (1983).

31. De Ruyter, K., Bloemer, J., and Peeters, P.: Merging Service Quality and Service Satisfaction, An Empirical Test of an Integrative Model. Journal of Economic Psychology 18, 387-406 (1997).

32. Oliver, R. L.: Satisfaction: A Behavioral Perspective on the Consumer, The McGraw-Hill Companies, Inc., New York, 1997.

33. Hofstede, G.: Culture's Consequences: International Differences in WorkRelated Values. Sage Publications, Beverly Hills, CA, 1980.

34. Hofstede, G.: Cultures and Organizations: Software of the Mind. McGrawHill Book Company, London, 1991. 
35. Riddle, D. I.: Leveraging Cultural Factors in International Service Delivery. Advances in Services Marketing and Management 1, 297-322 (1992).

36. Meldrum, M. J.: Marketing High-Tech Products: The Emerging Themes. European Journal of Marketing 29, 45-58 (1995).

37. Rust, R. T., Zahorik, A. J., and Keiningham, T. L.: Service Marketing, Harper Collins College Publishers, New York, 1996.

38. Parasuraman, A., Zeithaml, V. A., and Berry, L. L.: A Conceptual Model of Service Quality and Its Implications for Future Research. Journal of Marketing 49, 41-50 (1985).

39. Brislin, R. W.: Translation and Content Analysis of Oral and Written Materials, in Handbook of Cross-Cultural Psychology Vol. 2: Methodology, H. C. Triandis and J. W. Berry, eds., Allyn and Bacon, Boston, 1980, 389-444.

40. Cronin Jr., J. J., and Taylor, S. A.: Measuring Service Quality: A Reexamination and Extension, Journal of Marketing 56, 55-68 (1992).

41. Nunnally, J. C., and Bernstein, I. H.: Psychometric Theory, McGraw-Hill, Inc., New York, 1994.

42. Mokken, R. J.: A Theory and Procedure of Scale Analysis, Mouton, The Hague, 1971.

43. Mokken, R. J. and Lewis, C.: A Nonparametric Approach to the Analysis of Dichotomous Item Responses. Applied Psychological Measurement 6, 417-430 (1982)

44. Mokken, R. J., Lewis, C., and Sijtsma, K.: Rejoinder to "The Mokken Scale: A Critical Discussion”. Applied Psychological Measurement 10, 279-285 (1986)

45. Pedhazur, E. J. and Pedhazur Schmelkin, L.: Measurement, Design, and Analysis: An Integrated Approach. Lawrence Erlbaum Associates Publishers, Hillsdale, NJ, 1991.

46. Hoerl, A. E., and Kennard, R. W.: Ridge Regression: Biased Estimation for Nonorthogonal Problems. Technometrics 12, 55-67 (1970).

47. Hoerl, A. E., and Kennard, R. W.: Ridge Regression: Applications to Nonorthogonal Problems. Technometrics 12, 69-82 (1970).

48. Montgomery, D. C., and Peck, E. A.: Introduction to Linear Regression Analysis, 2nd edition, John Wiley \& Sons, Inc., New York, 1992.

49. Smith, P. B., and Schwartz, S.: Values in Handbook of Cross-Cultural Psychology, Vol. 3: Social Behavior and Applications, 2nd ed., J. W. Berry, M. H. Segall, and C. Kagikibasi, eds., Allyn and Bacon, Boston, 1997, 76-129. 